\title{
Parameters associated with growth factors of five fish species in the Atrai River, Dinajpur, Bangladesh
}

\author{
M. R. Islam ${ }^{1 *}$ and M. G. Azom ${ }^{2}$ \\ ${ }^{I}$ Department of Fisheries Biology and Genetics, Hajee Mohammad Danesh Science and Technology University, \\ Dinajpur-5200, Bangladesh \\ ${ }^{2}$ Faculty of Fisheries, Hajee Mohammad Danesh Science and Technology University, Dinajpur-5200, Bangladesh
}

Received: 20 July 2017

Revised: 05 September 2017

Accepted: 24 September 2017

DOI: http://dx.doi.org/10.3329/bjsir.v53i2.36677

\begin{abstract}
For evaluation of Fulton's condition factor $\left(C F_{\mathrm{f}}\right)$, relative body weight $\left(B W_{\mathrm{r}}\right)$ and form $\left(a_{3.0}\right)$ factor affecting growth, 5 fishes (Aspidoparia jaya, Gagata cenia, G. youssoufi, Salmophasia bacaila and $S$. phulo) were collected from the Atari River in Dinajpur district of Bangladesh. Significant differences $(p<0.05)$ were recorded among the values of $C F_{\mathrm{f}}(0.47-1.56)$ but not for $B W_{\mathrm{r}}(79.60$ 128.39). Based on $C F_{\mathrm{f}}$ values, analysis of similarities (ANOSIM, $p<0.01$ ) revealed that maximum distances $(R=0.9946)$ were found between $G$. youssoufi and $S$. bacaila while lowest $(R=0.2175)$ between $G$. cenia and $S$. phulo. Using two-dimensional nMDS scaling of $C F_{\mathrm{f}}$ and $B W_{\mathrm{r}}, G$. youssoufi showed good health condition $\left(C F_{\mathrm{f}}=1.22 \pm 0.01 ; B W_{\mathrm{r}}=100.63 \pm 0.79\right)$ and were separated (stress = $0.0003)$ from other fishes. Lowest $a_{3.0}$ value was noted for $S$. bacaila $(0.004)$ and highest for $G$. youssouf ( 0.012$)$. Therefore, G. youssoufi showed healthier and former body with more adaptability in this river than those of others. These are the first records for proper management of above mentioned fish species and future research in the near future.
\end{abstract}

Keywords: Condition factors; Small fishes; Atrai river

\section{Introduction}

Body condition of fishes is an indicator for morphology and growth (Froese, 2006). Condition factors $(C F \mathrm{~s})$ are commonly used to know the health status, physiology, reproduction and survival (Didenko et al. 2004; Richter, 2007) and to compare relative health of fishes (Froese, 2006). Fulton's condition factor $\left(C F_{f}\right)$, free from regression parameters $(a \& b)$, exploited to know the physical status of fishes. It is applied to alter two-dimensional length-weight relationship (LWR) statistic into single value to be a sign of energy stores in fishes under an isometric growth. Nevertheless, this assumption is infringed in $C F_{\mathrm{f}}$ and lengths relationship during allometric growth pattern $(3<b>3)$ of fishes (Lambert and Dutil, 1997). Relative body weight $\left(B W_{\mathrm{r}}\right)$ is an indicator to know the common condition of fishes representing an individual under better $(>1$ or 100) or worse ( $<1$ or 100) condition (Le Cren, 1951). The Atrai River, major river in Dinajpur district of Bangladesh, is a suitable ground for 74 freshwater fishes (Chaki et al. 2014) where Aspidoparia jaya, Gagata cenia (Hamilton 1822), G. youssoufi (Rahman 1976), Salmophasia bacaila (Hamilton 1822 ) and $S$. phulo are common native species. Therefore, aim is to explore sufficient information on $C F_{\mathrm{f}}, B W_{\mathrm{r}}$ and $a_{3.0}$ for these small fishes (except $G$. cenia reported by Chaki et al., 2013) in the Atrai River which might be helpful as a guidance future research workers.

\section{Materials and methods}

Five fish species (A. jaya, G. cenia, G. youssoufi, S. bacaila and S. phulo) were caught monthly (by fishermen) using seine net $\left(15 \times 3.5 \mathrm{~m}^{2}, 4 \mathrm{~mm}\right)$, gillnet $\left(12 \times 0.9 \mathrm{~m}^{2}, 15 \mathrm{~mm}\right)$ or cast net $(4$ $\times 6.75 \mathrm{~m}^{2}, 8 \mathrm{~mm}$ ) from July to December, 2015 in the Atrai River $\left(25.924^{\circ} \mathrm{N} 88.724^{\circ} \mathrm{E}\right)$ of Dinajpur district of Bangladesh. The captured fishes were immediately (within 1.5 hours) transported to laboratory using ice box. Total length $(T L)$ and standard length $(S L)$ were measured with a vernier caliper to the nearest $0.1 \mathrm{~cm}$. Body weight $(B W)$ were taken with a digital balance (HD-602ND, MEGA, Japan) to the nearest $0.1 \mathrm{~g}$. Length-weight relationships (LWRs) were calculated through logarithmic transformation of linear regression equation as $\log$ $B W=\log a+b \log T L$, where $B W$ is body weight (g), $T L$ total length $(\mathrm{cm})$ of fishes, $a$ intercept and $b$ slope of regression curve (Islam et al., 2017; Islam et al., 2018). The log-log plots for LWRs were exploited to eliminate the outliers (Froese, 2006).

\footnotetext{
*Corresponding author e-mail: mrislam_fbg@hstu.ac.bd
} 


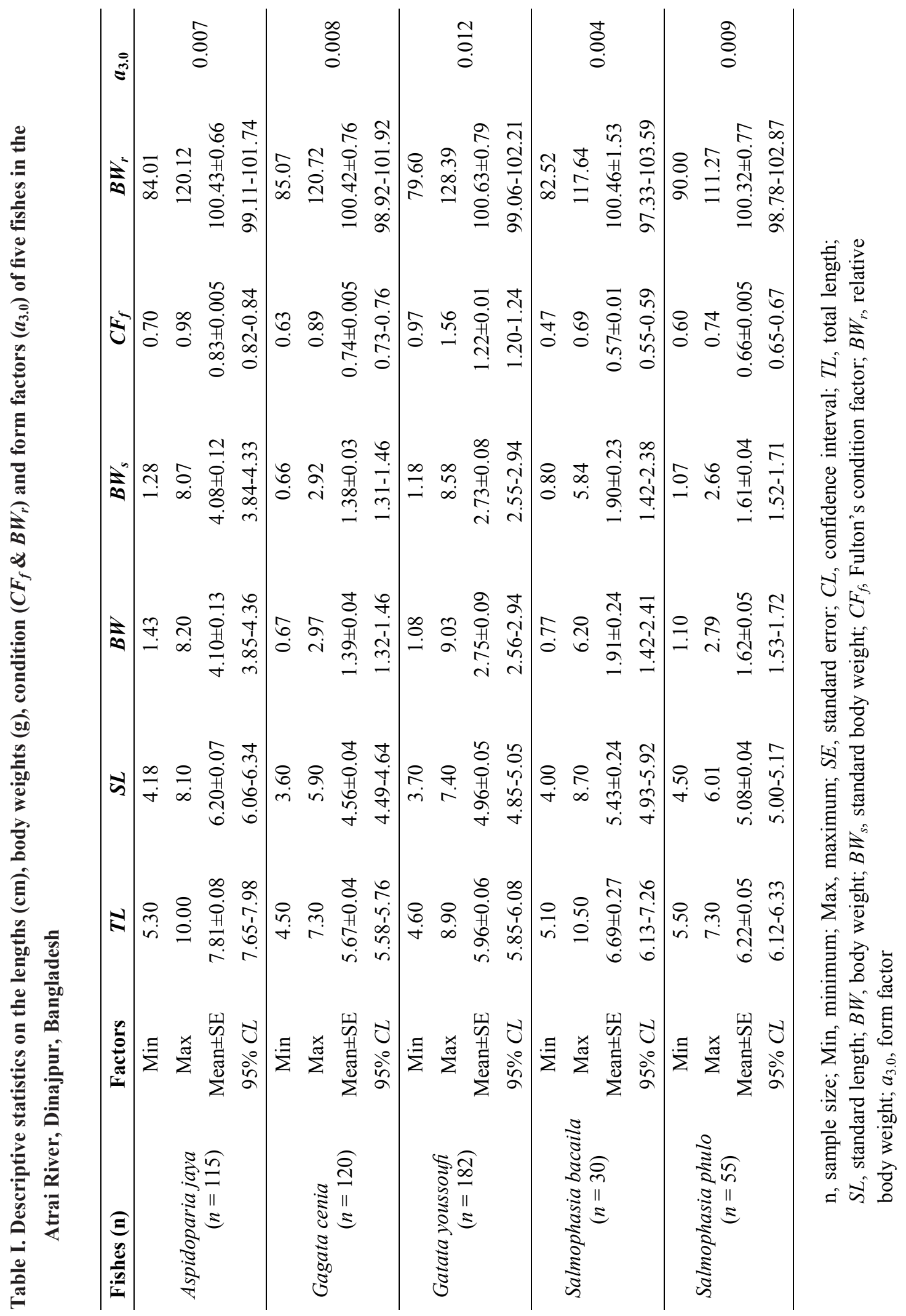


To estimate the condition (Fulton's, $C F_{\mathrm{f}}$ and relative body weight, $\left.B W_{\mathrm{r}}\right)$ and form $\left(a_{3.0}\right)$ factors, regression parameters $a$ and $b$ were obtained from previously calculated LWRs (log $T L$ vs. $\log B W$ ) followed by Islam and Mia (2016). Where, the earlier values of $a$ and $b$ are noted as 0.010 and 2.899 for $A$. jaya, 0.006 and 3.059 for G. cenia, 0.012 and 3.004 for $G$. youssoufi, 0.009 and 2.755 for S. bacaila, and 0.004 and 3.222 for S. phulo, respectively in the Atrai River, Dinajpur, Bangladesh. However, condition factors $(C F \mathrm{~s})$ were measured to recognize the health condition of these fishes where Fulton's condition factor was calculated as $C F_{f}=(B W$ $\times 100) / T L^{3}$ (Fulton, 1904) and relative body weight as $B W_{r}=$ $\left(B W / a T L^{b}\right) \times 100$ (Froese, 2006). Where, $B W$ is body weight (g), $T L$ total length $(\mathrm{cm})$ while $a$ and $b$ are regression parameters previously estimated from LWRs by Islam and Mia (2016). According to Froese (2006), form factor $\left(a_{3.0}\right)$ was estimated through an equation as $a_{3.0}=10 \log a-S(b-3)$, where $a$ and $b$ (formerly computed) from LWRs as regression parameters. Then, mean slope $S=-1.358$ was used to calculate $a_{3.0}$ for these fish species. Using $C F_{f}$ and $B W_{\mathrm{r}}$ values, one-way analysis of variance (ANOVA) and one-way analysis of similarities (ANOSIM) were tested to notice dissimilarities $(p<0.05)$ among fishes. Two-dimensional nonmetric multidimensional scaling (nMDS) was taken to measure the remoteness among fishes after logarithming transform of $C F_{f}$ and $B W_{\mathrm{r}}$ values. All statistical tests were done using SPSS (IBM corporation, version 22), PAST (Paleontological statistics, version 3.10) software and Microsoft Office Excel, 2013.

\section{Results and discussion}

A total of 502 specimens belonging to five species were captured from the Atrai River, Dinajpur, Bangladesh. Descriptive statistics on lengths ( $T L$ and $S L$ ), body weights $\left(B W\right.$ and $\left.B W_{s}\right)$ and condition factors $\left(C F_{f}, B W_{r}\right.$ and $\left.a_{3.0}\right)$ of these species are given in Table I and Fig. 1. Fulton's $\left(C F_{\mathrm{f}}>\right.$ $0.57 \pm 0.01)$ condition factor was significantly assorted $(F=$ $863.40, p<0.05)$ among species. The values of $C F_{\mathrm{f}}$ were statistically higher $\left(t_{\mathrm{s}}=23.05\right)$ in G. youssoufi and lower ($\left.64.51<t_{\mathrm{s}}>-30.19\right)$ in A. jaya, G. cenia, S. bacaila and $S$. phulo, respectively. In $B W_{\mathrm{r}}$, no significant changes $\left(B W_{r}>\right.$ $100.32, F=0.02)$ were recorded within $\left(0.30<t_{\mathrm{s}}>0.80, p>\right.$ $0.43)$ and between $\left(t_{\mathrm{s}}=1.25, p=0.21\right)$ species from 100 , respectively. Form factor $\left(a_{3.0}\right)$ was used to discern body shape of a fish or population from others. To the best of knowledge, it was not possible to judge the present findings against others due to lack of literature on condition (except $C F_{\mathrm{f}}$ of G. cenia by Chaki et al. 2013; S. bacaila by Masud and Singh, 2015) and form factors $\left(a_{30}\right)$. The present mean values of $T L$ and $B W$ are higher than the values for $A$. jaya (2.75-7.81 cm and 0.14-3.67 g, Kaushik et al., 2015) may be

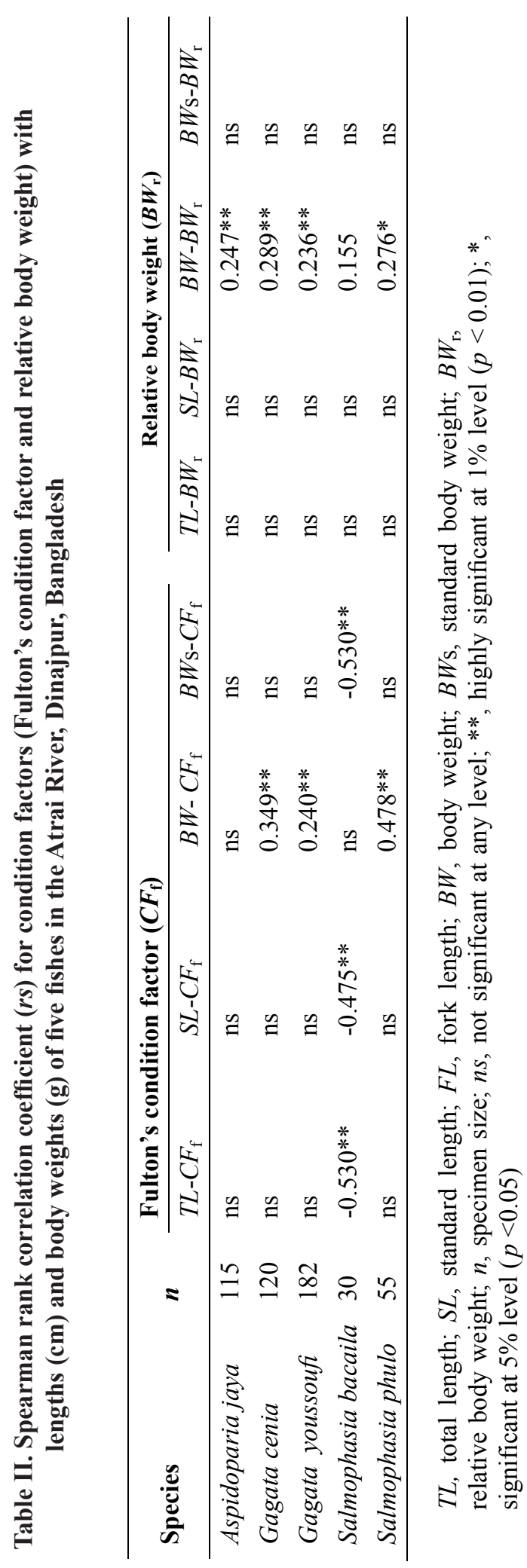


due to geographical variation but are within the limits for $G$. cenia (5.50-6.65 cm, Chaki et al., 2013), S. bacaila (3.40-15.20 cm, Masud and Singh, 2015) and S. phulo (6.00-10.70 $\mathrm{cm}$ and 1.36-7.21 g, Siddik et al., 2016), respectively. As there is a first record on length and body weight of G. youssoufi in the Atrai River (Islam and Mia, 2016), so no comparison was possible against this value with the previous one. According to Barnham and Baxter (1998), a fish is meager and elongated with lean body $\left(C F_{\mathrm{f}}=1.0\right)$, sound health $\left(C F_{\mathrm{f}}=1.20\right)$ and healthy body $\left(C F_{\mathrm{f}}=1.40\right)$. Along with values, only $G$. youssoufi $\left(C F_{\mathrm{f}}=1.22 \pm 0.009\right)$ was in good body shape but rest of the fishes collected from this river had poor, thin and extended body shape $\left(C F_{\mathrm{F}}>\right.$ $0.57 \pm 0.01)$. The present $C F_{\mathrm{f}}$ value of $G$. cenia $(0.74 \pm 0.005)$ is out of range ( $1.62 \pm 0.28$ to $2.01 \pm 0.26)$ report by Chaki et al. (2013) may be due to food staff and gonad maturation (Gupta et al., 2011). $B W_{\mathrm{r}}$ is used to know the prey availability, food abundance and sexual maturity of fishes (Anderson and Neumann, 1996). If $B W_{\mathrm{r}}$ values of a fish were below 100 pointed to minimum prey or maximum predator availability and vice-versa (Froese, 2006; Rypel and Richter, 2008). In this study, values of $B W_{\mathrm{r}}$ for all fishes were very close to 100 proposing good relation with food organisms and predators representing good aquatic ecosystem in the Atrai River where hydrological parameters were less responsible to reduce fish availability than those of other factors such as overfishing and habitat fragmentation (Mijkherjee et al., 2002). In this river, majority of fishes were within expected range (0.00775-0.00906) of $a_{3.0}$ representing elongated body shape except for G. youssoufi (0.012, maximum) and S. bacaila (0.004, minimum) because of their more and less body height respectively (Froese, 2006).

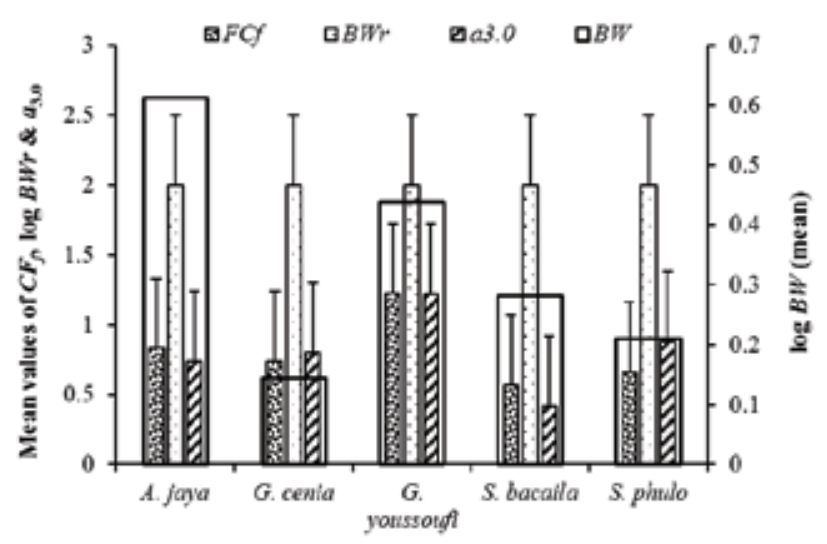

Fig. 1. Mean values of $C F_{\mathrm{f}}, \log B W \mathrm{r}$ and $a 3.0$ (multiplied by 100) with error bars associated with $\log B W$ for five fishes in the Atrai River, Dinajpur, Bangladesh 


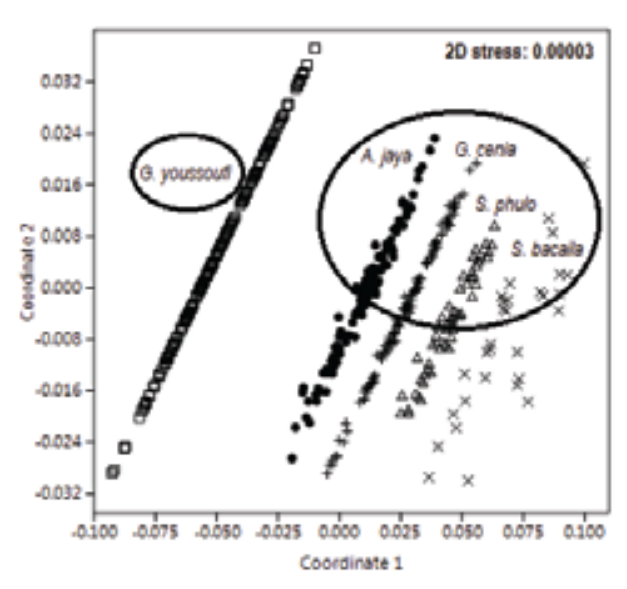

Fig. 2. Two dimensional nMDS scaling of $C F_{\mathrm{f}}$ and $B W r$ among five fishes (•A. jaya; +G. cenia; $\square \boldsymbol{G}$. youssoufi; $\times S$. bacaila \& $\Delta S$. phulo) in the Atrai River, Dinajpur, Bangladesh

A Spearman rank test $\left(r_{\mathrm{s}}\right)$ was carried out (Table II) for CFs with lengths $(\mathrm{cm})$ and body weights $(\mathrm{g})$ of these species in this river. Based on Euclidean method, analysis of similarity (ANOSIM) represented significant dissimilarity $(R=0.6657$, $p<0.01)$ among $C F_{\mathrm{f}}$ values of fish species while no variations were noticed among $B W_{\mathrm{r}}$ values $(R=-0.039, p=$ 1.0). In case of $C F_{\mathrm{f}}$, maximum variation $(R=0.9946, p<$ $0.01)$ was found between $G$. youssoufi and $S$. bacaila but lowest $(R=0.2175, p<0.01)$ was recorded between $G$. cenia and $S$. phulo (Table III). A two-dimensional ordination of nMDS (Euclidean's similarity index) based on the values of $C F_{\mathrm{f}}$ and $B W_{\mathrm{r}}$ proposed that G. youssoufi was isolated from other four species stressing as 0.00003 (Figure 2). Based on Spearman rank test, $C F_{\mathrm{f}}$ was significantly $(p<0.01$ or $<0.05)$ associated with $B W$ for $G$. cenia, G. youssoufi and $S$. phulo ( $p$ $<0.01$ or $<0.05$ ), but not for A. jaya and S. bacaila. TL, $S L$ and $B W_{\mathrm{s}}$ were correlated $\left(p<0.01\right.$ or $<0.05$ ) with $C F_{\mathrm{f}}$ only for $S$. bacaila excluding other fishes which was differed for G. cenia (Chaki et al., 2013) may be due to temporal and sexual variations. Again, $B W_{\mathrm{r}}$ was significantly $(p<0.01$ or $<$ 0.05 ) interrelated with $B W$ for all fishes except $S$. bacaila while no significant relationships were observed with lengths ( $T L$ and $S L$ ). Although no earlier findings are found to compare with these relationships but more or less similar results were observed on different five fishes in the Jamuna River of Bangladesh (Hossain et al., 2012). Using ANOSIM analysis, significance differences $(R=0.07, p<0.01)$ were observed among morphometric data of Acanthocybium solandri (Zischke et al. 2013) disagreed with present study may be due to different species and geographical area. The values of $C F_{\mathrm{f}}$ and $B W_{\mathrm{r}}$ suggested that $G$. youssoufi was secluded from another species may be due to morphometrics and body shape controlled by a number of environmental and heredity factors (Cadrin, 2000) that were not measured during this study.

Lastly, conditions factors of fishes are recognized parameters in fishery management that can friendly support the existence of A. jaya, G. cenia, G. youssoufi, S. bacaila and S. phulo where $G$. youssoufi showed more healthy and strong body representing to have more adaptive capability than those of other related fish species existing in this river.

\section{Acknowledgements}

Authors are thankful to fishermen and students (Faculty of Fisheries, HSTU) for capturing and measuring fish specimens from the Atrai River (Dinajpur, Bangladesh).

\section{References}

Anderson RO and Neumann RM (1996), Length, weight and associated structure indices In: Fisheries Techniques, $2^{\text {nd }}$ Ed (American Fisheries Society), pp 447-482.

Barnham C and Baxter A (1998), Condition factor ' $\mathrm{K}$ ' for Salmonid fish, Fish Notes, pp 1-3.

Cadrin SX (2000), Advances in morphometric identification of fishery stocks, Rev Fish Biol Fish. 10: 91-112. DOI: 10.1023/A:1008939104413

Chaki N, Jahan S, Fahad MFH, Galib SM and Mohsin ABM (2014), Environment and fish fauna of the Atrai River: global and local conservation perspective, J Fish. 2: 163-172. DOI: 10.1023/A:1008939104413

Chaki N, Joadder MAR and Fahad MFH (2013), Lengths, length-length relationships and condition factor of Indian catfish Gagata cenia (Hamilton, 1822) in the Padma River, Bangladesh, J Fish. 1: 22-29. DOI: 10.17017/jfish.v1i1.2013.6

Didenko AV, Bonar SA and Matter WJ (2004), Standard weight $(W \mathrm{~s})$ equations for four rare desert fishes, $N \mathrm{Am}$ J Fish Manage. 24: 697-703. DOI: 10.1577/M02-119.1

Froese R (2006), Cube law, condition factor and weight-length relationships: History, meta-analysis and recommendations, $J$ Appl Ichthyol. 22: 241-253. DOI: $10.1111 /$ j.1439-0426.2006.00805.x

Fulton TW (1904), The rate of growth of fishes, Report No. $22^{\text {nd }}$ Annual Report, Part III (Edinburgh, Scotland, Fisheries Board of Scotland), pp 141-241. 
Gupta BK, Sarkar UK, Bhardwaj SK and Pal A (2011), Condition factor, length-weight and length-weight relationships of an endangered fish Ompok pabda (Hamilton 1822) (Silurifomes: Siluridae) from the River Gomti, a tributary of the River Ganga, India, $J$ Appl Ichthyol. 27: 962-964. DOI: 10.1111/j.1439-0426.2010.01625.x

Hossain MY, Rahman MR, Jewel MAS, Ahmed ZF, Ahamed F, Fulanda B, Abdallah EM and Ohtomi J (2012), Conditions- and form-factor of the five threatened fishes from the Jamuna (Brahmaputra River Distributary) River, northern Bangladesh, Sains Malays. 41: 671-678.

Islam MR and Mia MJ (2016), Length-weight and length-length relationships of five fish species in the Atrai River, Dinajpur, Bangladesh, J Appl Ichthyol. 32: 1371-1373. DOI: $10.1111 /$ jai. 13210

Islam MR, Azom MG, Faridullah M and Mamun M (2017), Length-weight relationship and condition factor of 13 fish species collected from the Atrai and Brahmaputra rivers, Bangladesh. J Bio Env Sci. 10: 123-133.

Islam MR, Roy S, Mia MJ and Amin AKMR (2018), Length-weight and length-length relationships of four small fishes from the Atrai River, Dinajpur, Bangladesh, J Appl Ichthyol. 34: 200-202. DOI: 10.1111/jai.13531

Kaushik G, Das MK, Hussain JF and Bordoloi S (2015), Length-weight relationships of five fish species collected from Ranganadi River (Brahmaputra River tributary) in Assam, India, $J$ Appl Ichthyol. 31: 433-434. DOI: $10.1111 /$ jai.12691

Lambert Y and Dutil JD (1997), Can simple condition indices be used to monitor and quantify seasonal changes in the energy reserves of Atlantic cod (Gadus morhua)? Can J Fish Aquat Sci. 54: 104-112. DOI: 10.1139/f96-149
Le Cren ED (1951), The length-weight relationships and seasonal cycle in gonad weight and condition in the perch (Perca fluviatilis), J Anim Ecol. 20: 201-219. DOI: $10.2307 / 1540$

Masud S and Singh KP (2015), Studies on length-weight relationship and condition factor of Salmophasia bacaila (Hamilton) from the lower stretch of river Yamuna at Allahabad, Int J Fish Aquat Stud. 2: 147-150.

Mijkherjee M, Praharaj A and Das S (2002), Conservation of endangered fish stocks through artificial propagation and larval rearing technique in West Bengal, India, Aqua Asia 2: 8-11.

Richter TJ (2007), Development and evaluation of standard weight equations for bridge-lip suckers and large-scale suckers, $N$ Am J Fish Manage. 27: 936-939. DOI: 10.1577/M06-087.1

Rypel AL and Richter TJ (2008), Empirical percentile standard weight equation for the black tail red horse, $N$ Am J Fish Manage 28: 1843-1846. DOI: 10.1577/M07-193.1

Siddik MAB, Chaklader MR, Hanif MA, Islam MA and Fotedar R (2016), Length-weight relationships of four fish species from a coastal artisanal fishery, southern Bangladesh, J Appl Ichthyol 32: 1300-1302. DOI: 10.1111/jai.13181

Zischke MT, Griffiths SP, Tibbetts IR and Lester RJG (2013), Stock identification of wahoo (Acanthocybium solandri) in the Pacific and Indian Oceans using morphometrics and parasites, ICES J Mar Sci. 70: 164-172. DOI: 10.1093/icesjms/fss164 